\title{
The feasibility of crop diversification in rice based cropping systems in haor ecosystem
}

\author{
J. Shopan ${ }^{1}$, M. S. U. Bhuiya ${ }^{2}$, M. A. Kader ${ }^{2}$ and M. K. Hasan ${ }^{3}$ \\ ${ }^{1}$ Bangladesh Rice Research Institute, Gazipur, ${ }^{2}$ Department of Agronomy, Bangladesh Agricultural University, \\ Mymensingh-2202 and ${ }^{3}$ Department of Agricultural Chemistry, Sylhet Agricultural University, Sylhet-3100, \\ Bangladesh, E-mail: n_sparkle_04@yahoo.com
}

\begin{abstract}
An experiment was conducted in five farmers' field in Dingaputa haor of Purba Tetulia village, Mohangonj Upazila in Netrakona district during the period from 20 July 2010 to 15 May 2011. The objective of the study was to determine the feasibility of growing short duration vegetable and oil crops in seasonal fallow of Boro rice-Fallow-Fallow cropping patterns in terms of both combined yields and economic performance. Six short duration vegetables such as potato, red amaranth, stem amaranth, spinach, radish and mustard were the first crops and Boro rice (var. BRRI dhan28) was the second crop. Thus there were six types of cropping patterns Potato-Boro rice- Seasonal flood, Red amaranth-Boro rice- Seasonal flood, Stem amaranth-Boro rice- Seasonal flood, Spinach-Boro rice- Seasonal flood, Radish-Boro rice- Seasonal flood and Musturd-Boro rice- Seasonal flood. The agronomic productivity (rice equivalent yield $\mathrm{t} \mathrm{ha}^{-1}$ ) of the cropping patterns Potato-Boro rice- Seasonal flood, Red amaranth-Boro rice- Seasonal flood, Stem amarnth-Boro rice- Seasonal flood, Spinach-Boro rice- Seasonal flood, Radish-Boro rice- Seasonal flood and Mustard-Boro rice- Seasonal flood were 22.42, 15.47, 17.04, 17.79, 22.11 and $11.56 \mathrm{t} \mathrm{ha}^{-1}$, respectively with economic productivity (gross return Tk ha ${ }^{-1}$ ) of $364162.50,251712.50,276900.00,292012.50,359125.00$ and 187850.00 , respectively and the benefit cost ratio of $1.88,1.52,1.65,1.69,1.75$ and 1.12 , respectively From diversification practices in Dingaputa haor ecosystem Potato-Boro rice- Seasonal flood and Radish-Boro riceSeasonal flood cropping patterns were found to be the most dominant cropping patterns in economic terms.
\end{abstract}

Keywords: Crop diversification, Cropping system, Haor, Seasonal flood

\section{Introduction}

Haor is a bowl-shaped depression of typical low land area within the estuarine flood plain of the Surma, Kushiyara, Meghna, Dhenu and Ghorautre rivers. The haors of Bangladesh cover the districts of Kishoreganj (eastern part), Netrokona, Sunamganj, Habiganj, Moulabibazar and part of Sylhet and Brahmanbaria (Haor Task Force, 1985). The haor area extends as many as 43 upazilas of the aforesaid districts. The area of the haor is about 932793 hectares (Hossain and Bhuiya, 2011). The haors undergo deep flooding $(5-10 \mathrm{~m})$ from late May to October while it looks like a sea.

There is only one cropping season in haor i.e. the Rabi, when Boro rice, potato, groundnut, sweet potato, mustard, pulse, etc. are grown. The haor is highly potential area for rice production and fishery resources. It contributes over $10 \%$ to the national production of rice. An option to provide the nutritional security of the people in the haor area is to accommodate other crops such as vegetables, pulses, oil crops, etc. within the single rice cropping system being practiced in the area. Short duration vegetables such as red amaranth, stem amaranth, spinach, radish, potato, etc., oil crops such as mustard, groundnut, etc. and pulse crops such as black gram, lentil, etc. might be grown before cultivation of Boro rice (LIFCHASA, 2010) in land where flood water recedes fully at the end of October and first week of November. In this land type there is ample scope of crop diversification and crop intensification with the aversion of early flash flood in April. In fact such pioneering studies were done in the haors of Karimganj and Itna upazila in mid 1998 to 2000 and in Austagram, Nikli, Mithamain, Ajmiriganj and Sulla upazila in 2009 to 2011 by the Bangladesh Agricultural University, Mymemsingh in the name of FSES and ART of HISAL, respectively (Hossain et al., 2010a).

Crop diversification is the growing of different species of crops in a farm or area or region or nation either in succession or simultaneously or both together in the course of the year. While crop intensification is the growing of crop with intensive care and management by utilizing modern technique and technology to maximize production in a unit of land with the accommodation of more number of crops per year. 
The feasibility of crop diversification and intensification of Fallow-Boro rice-Seasonal flood water grown after early potato, red amaranth, stem amaranth, spinach, radish and mustard but not sacrifing Boro rice. The study was undertaken to determine the agro-economic performance of short duration vegetables and Boro rice varieties and pattern into Potato-Boro rice- Seasonal flood water, Red amaranth-Boro riceSeasonal flood water, Stem amaranth-Boro rice- Seasonal flood water, Spinach-Boro rice- Seasonal flood water, Radish-Boro rice- Seasonal flood water and Mustard-Boro rice- Seasonal flood water, respectively (Hossain and Kashem, 1995). The crop diversification has successfully been tried by the Action Research Team of the HISAL Project of the Ireland based NGO, the Concern Worldwide in recent years (Hossain et al., 2010b). From the findings it indicates that a series of cropping can be tried. For this reason, any designing of the cropping patterns should involve rice as the base crop of the patterns.

Although Bangladesh is nearly self-sufficient in rice production, other foods such as vegetables, pulses, oil crops etc. are still deficit to a large extent. Even rice food security has not been achieved at the household level in many poor and extreme poor farm families. Crop diversification as mentioned above will increase cropping intensity, raising the productivity of land and labour, generate income and employment which in turn will eliminate food and nutritional insecurity and poverty of farming community of the haor area. A study was, therefore, undertaken in Purbo Tethulia of the ecosystems of Dingaputa haor with the following objectives.

1. To explore the possibility of growing short duration vegetable and oil crop before Boro rice of Fallow- Boro rice - Seasonal flood water.

2. To evaluate the agro-economic performance of the designed cropping patterns.

3. To assess farmers' response on the acceptability of designed patterns of the trial.

\section{Materials and Methods}

The experiment was carried out at Purbo Tethulia situated in the eastern side of Mohangonj upazila of Netrakona district, a village and Ward of Tethulia union in Dingaputa haor, during the period from October 2010 to May 2011. The experimental site was a representative of flood prone haor area which covers 932793 ha i.e. about $6.5 \%$ area of Bangladesh. Experimental treatment consisted of six designed patterns for diversification of rice cropping systems. The patterns were designed against Fallow- Boro rice- Seasonal flood (in post flood period as shown in Fig. 1) along with crops intervened with underline. The six designed patterns were-

1. Potato-Boro rice- Seasonal flood

2. Red amaranth-Boro rice- Seasonal flood

3. Stem amaranth-Boro rice- Seasonal flood

4. Spinach-Boro rice- Seasonal flood

5. Radish-Boro rice- Seasonal flood

6. Mustard-Boro rice- Seasonal flood

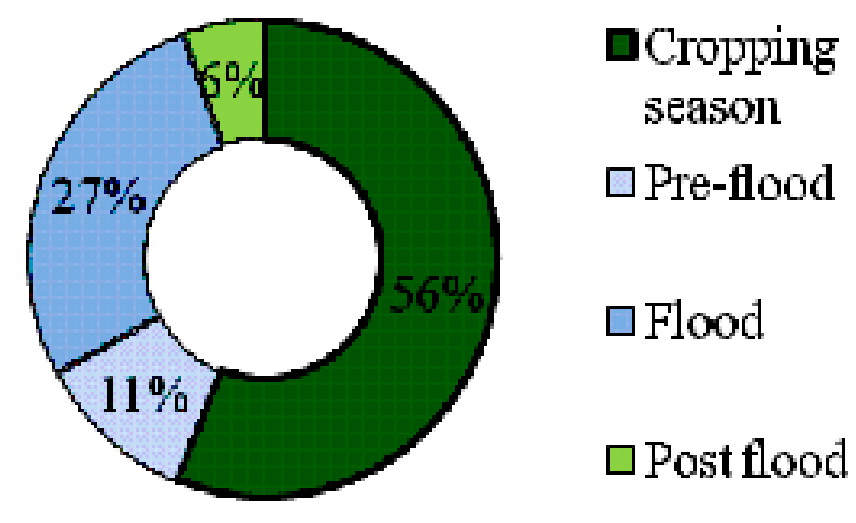

Fig. 1. Cropping season and flood in haor eco-system 
Experiment was laid out in a randomized complete block design with five farmers' dispersed replications. Layout of the experiment was done on 20 October 2010. There were 30 unit plots of same size. Plot to plot and block to block distances were $0.75 \mathrm{~m}$ and $1.00 \mathrm{~m}$, respectively. The collected data were compiled and tabulated in proper form and subjected for statistical analysis. Data were analyzed using the "Analyses of variance" technique with the help of computer package MSTAT and differences among treatment means were adjudged with Duncan's Multiple Range Test (DMRT) as outlined by Gomez and Gomez (1984).

\section{Results and Discussion}

Results obtained from the present study have been presented and discussed here under different sections comprising yield and yield contributing characters of rice, vegetable yield, rice equivalent yield and economic analysis. Experimental results have been presented in Tables 1-2. Haor rice crop ecosystem is constrained by a number of factors such as topography, time of receeding flood water, planting and harvesting time, cold injury for rice, etc. Vegetable-Boro rice- Seasonal flood water is the single crop. Pattern practiced over there in most of the land. Boro rice is occasionally destroyed by early flash flood at the grain development and mature stage which generally occurs as early as last week of March. The cycle of occurrence of the flash flood is 4 years. The last flash flood occurred in the Dingaputa Haor on 28 March 2010 (LIFCHASA, 2010). Depending upon draining flood water from the crop field the cropping period in the haor area starts from last week of October and lasts up to the end of April (Fig. 1), crop growth duration for Vegetable-Boro rice- Seasonal flood water cycle is shown in (Fig. 2) and Rice equivalent grain yield are graphically represented in (Fig. 3) similar results were reported by Hossain et al. (2010c).

Table1. Productivity of Vegetable-Boro rice-Fallow cropping pattern in Dingaputa haor ecosystem

\begin{tabular}{|c|c|c|c|c|c|c|c|c|}
\hline \multirow{3}{*}{ Cropping pattern } & \multicolumn{2}{|c|}{ Vegetable yield $\left(\mathrm{t} \mathrm{ha}^{-1}\right)$} & \multirow{2}{*}{$\begin{array}{l}\text { Rice equivalent yield } \\
\text { t ha-1 }^{-1} \text { (vegetable) }\end{array}$} & \multirow{2}{*}{$\begin{array}{l}\text { Grain } \\
\text { yield } \\
\left(\mathrm{t} \mathrm{ha}^{-1}\right) \\
\end{array}$} & \multirow{2}{*}{$\begin{array}{l}\text { Straw } \\
\text { yield } \\
\left(\mathrm{t} \mathrm{ha}^{-1}\right)\end{array}$} & \multirow{2}{*}{$\begin{array}{l}\text { Rice equivalent } \\
\left.\text { yield ( } \mathrm{t} \mathrm{ha}^{-1}\right)\end{array}$} & \multirow{2}{*}{$\begin{array}{l}\text { Total grain } \\
\text { yield }\left(\mathrm{t}^{\text {ha-1) }}\right)\end{array}$} & \multirow{2}{*}{$\begin{array}{c}\text { Total rice } \\
\text { equivalent yield } \\
(\mathrm{t} \text { ha-1) }\end{array}$} \\
\hline & Product & By product & & & & & & \\
\hline & 1 & 2 & 3 & 4 & 5 & 6 & $4+6$ & $3+7$ \\
\hline Potato-Boro rice-Fallow & 18.00 & - & 13.29 & 8.51 & 9.98 & 0.61 & 9.13 & $22.42 a^{*}$ \\
\hline Red amaranth-Boro rice-Fallow & 10.30 & - & 6.33 & 8.54 & 9.89 & 0.60 & 9.14 & $15.47 \mathrm{~d}$ \\
\hline Stem amaranth-Boro riceFallow & 22.00 & - & 8.12 & 8.32 & 9.66 & 0.59 & 8.92 & $17.04 \mathrm{c}$ \\
\hline Spinach-Boro rice-Fallow & 12.00 & - & 8.86 & 8.51 & 9.82 & 0.60 & 9.11 & $17.97 \mathrm{~b}$ \\
\hline Radish-Boro rice-Fallow & 52.00 & - & 12.79 & 8.71 & 9.82 & 0.61 & 9.32 & $22.11 \mathrm{a}$ \\
\hline Mustard-Boro rice-Fallow & 1.01 & 2.55 & 2.49 & 8.47 & 9.82 & 0.60 & 9.07 & $11.56 \mathrm{e}$ \\
\hline Level of significance & NS & NS & NS & NS & NS & NS & NS & 0.01 \\
\hline$s \bar{x}$ & 0.22 & - & - & 0.18 & 0.18 & - & - & 0.19 \\
\hline CV (\%) & 2.65 & - & - & 4.92 & 4.04 & - & - & 2.44 \\
\hline
\end{tabular}

*Figures in column bearing dissimilar letters differ significantly whereas figures bearing similar letter(s) do not differ significantly at $1 \%$ level of probability. By product is not substantial and not included in the calculation.

NS = Not significant

Table 2. Duration of cropping patterns and occurrence of the flash flood

\begin{tabular}{|c|c|c|c|c|c|c|c|c|c|c|c|}
\hline \multirow[b]{2}{*}{$\begin{array}{l}\text { Cropping } \\
\text { pattern }\end{array}$} & \multirow{2}{*}{$\begin{array}{l}\text { Planting } \\
\text { time of } \\
\text { first crop }\end{array}$} & \multirow{2}{*}{$\begin{array}{l}\text { Duration } \\
\text { of the } \\
\text { first crop } \\
\text { (Day) }\end{array}$} & \multirow{2}{*}{$\begin{array}{l}\text { Turn } \\
\text { around } \\
\text { period } \\
\text { (Day) }\end{array}$} & \multirow{2}{*}{$\begin{array}{l}\text { Planting } \\
\text { time of } \\
\text { second } \\
\text { crop }\end{array}$} & \multirow{2}{*}{$\begin{array}{l}\text { Duration of } \\
\text { the } \\
\text { second crop } \\
\text { (Day) }\end{array}$} & \multirow{2}{*}{$\begin{array}{l}\text { Duration of the } \\
\text { pattern (first crop+ } \\
\text { turn around period+ } \\
\text { second crop) }\end{array}$} & \multicolumn{5}{|c|}{$\begin{array}{l}\text { Possibility avoiding early flash flood } \\
\text { (before last } 28 \text { March) an estimation }\end{array}$} \\
\hline & & & & & & & \begin{tabular}{|c|} 
Shifting planting/ \\
transplanting \\
date to
\end{tabular} & $\begin{array}{l}\text { Curtailing duration } \\
\text { of turn around } \\
\text { period for Boro rice }\end{array}$ & \begin{tabular}{|c|} 
Earliness \\
advantage \\
obtained for rice
\end{tabular} & $\begin{array}{c}\text { Probable } \\
\text { harvesting } \\
\text { date }\end{array}$ & $\begin{array}{c}\text { Probability of risk } \\
\text { prone to flash } \\
\text { flood * }\end{array}$ \\
\hline 1 & 2 & 3 & 4 & 5 & 6 & 7 & 8 & 9 & $10(8+9)$ & 11 & 12 \\
\hline $\mathrm{P}_{1}$ & 4 Nov. & 71 & 10 & 25 Jan. & 93 & 174 & 20 Oct. & 7 & 17 & 11April & Risk prone \\
\hline $\mathrm{P}_{2}$ & 9 Nov. & 26 & 50 & 25 Jan. & 93 & 169 & 20 Oct. & 25 & 34 & 24March & Risk aversive \\
\hline $\mathrm{P}_{3}$ & 9 Nov. & 53 & 23 & 25 Jan. & 93 & 169 & 20 Oct. & 15 & 27 & 1April & Risk prone \\
\hline $\mathrm{P}_{4}$ & 9 Nov. & 30 & 46 & 25 Jan. & 93 & 169 & 20 Oct. & 25 & 40 & 18March & Risk aversive \\
\hline $\mathrm{P}_{5}$ & 4 Nov. & 71 & 10 & 25 Jan. & 93 & 174 & 20 Oct. & 7 & 22 & 6Apri & Risk prone \\
\hline$P_{6}$ & 4 Nov. & 76 & 5 & 25 Jan. & 93 & 174 & 20 Oct. & $\begin{array}{l}\text { Too short to } \\
\text { shorten }\end{array}$ & 14 & 14April & Risk prone \\
\hline
\end{tabular}

$\mathrm{P}_{1}=$ Potato-Boro rice-Fallow, $\mathrm{P}_{2}=$ Red amaranth-Boro rice-Fallow, $\mathrm{P}_{3}=$ Stem amaranth-Boro rice-Fallow, $\mathrm{P}_{4}=$ Spinach-Boro rice-Fallow, $\mathrm{P}_{5}=$ Radish-Boro rice-Fallow, $\mathrm{P}_{6}=$ Mustard-Boro rice-Fallow

*Latest flash flood occurred in Dingaputa haor area on 28 March, 2010 based upon this flash flood occurrence the possibility avoiding early flash flood as shown in the table has been prepared 


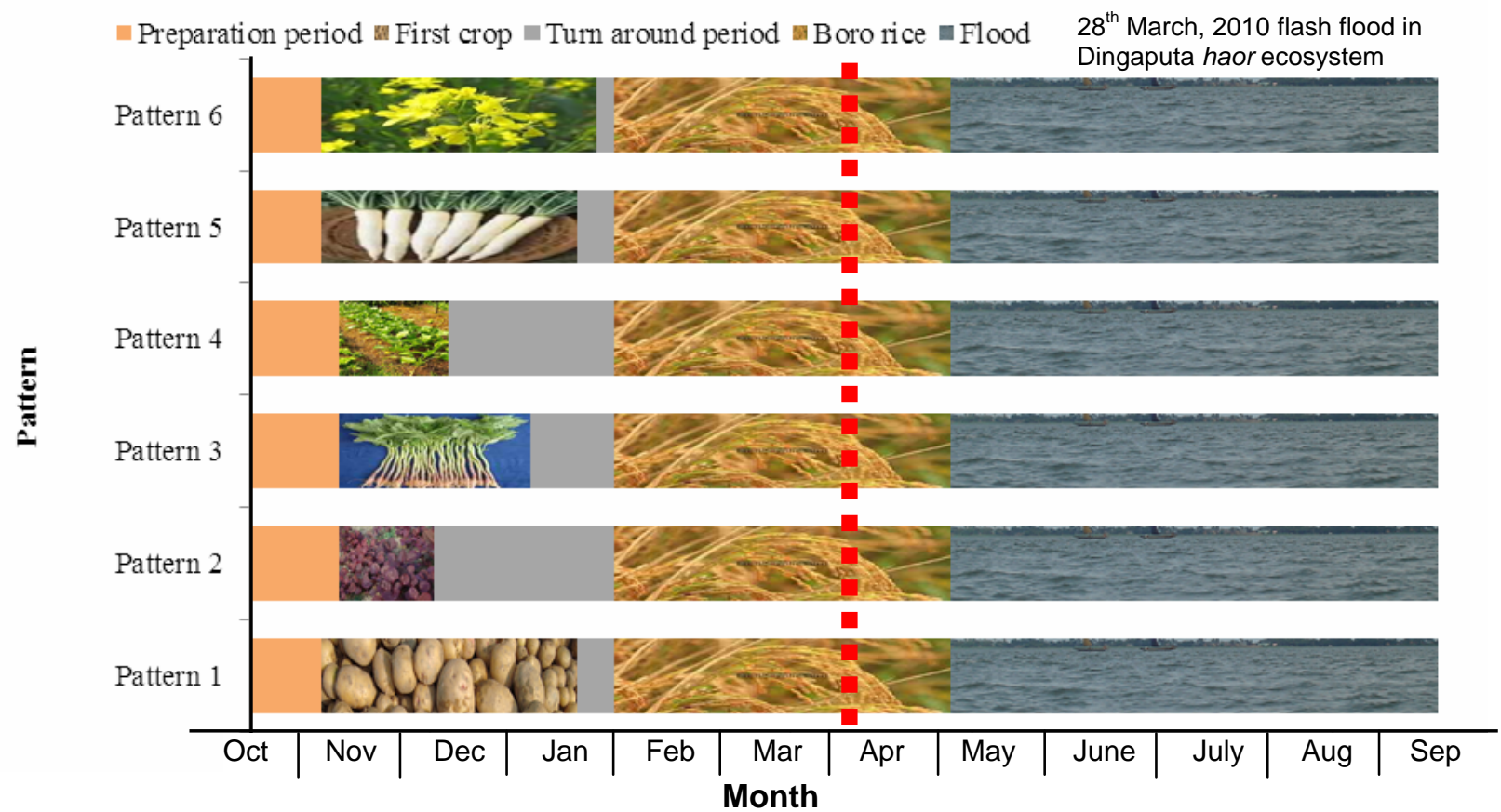

Fig. 2. Crop growth duration for Vegetable-Boro rice- Seasonal flood water pattern occurrence in Dingaputa haor ecosystem

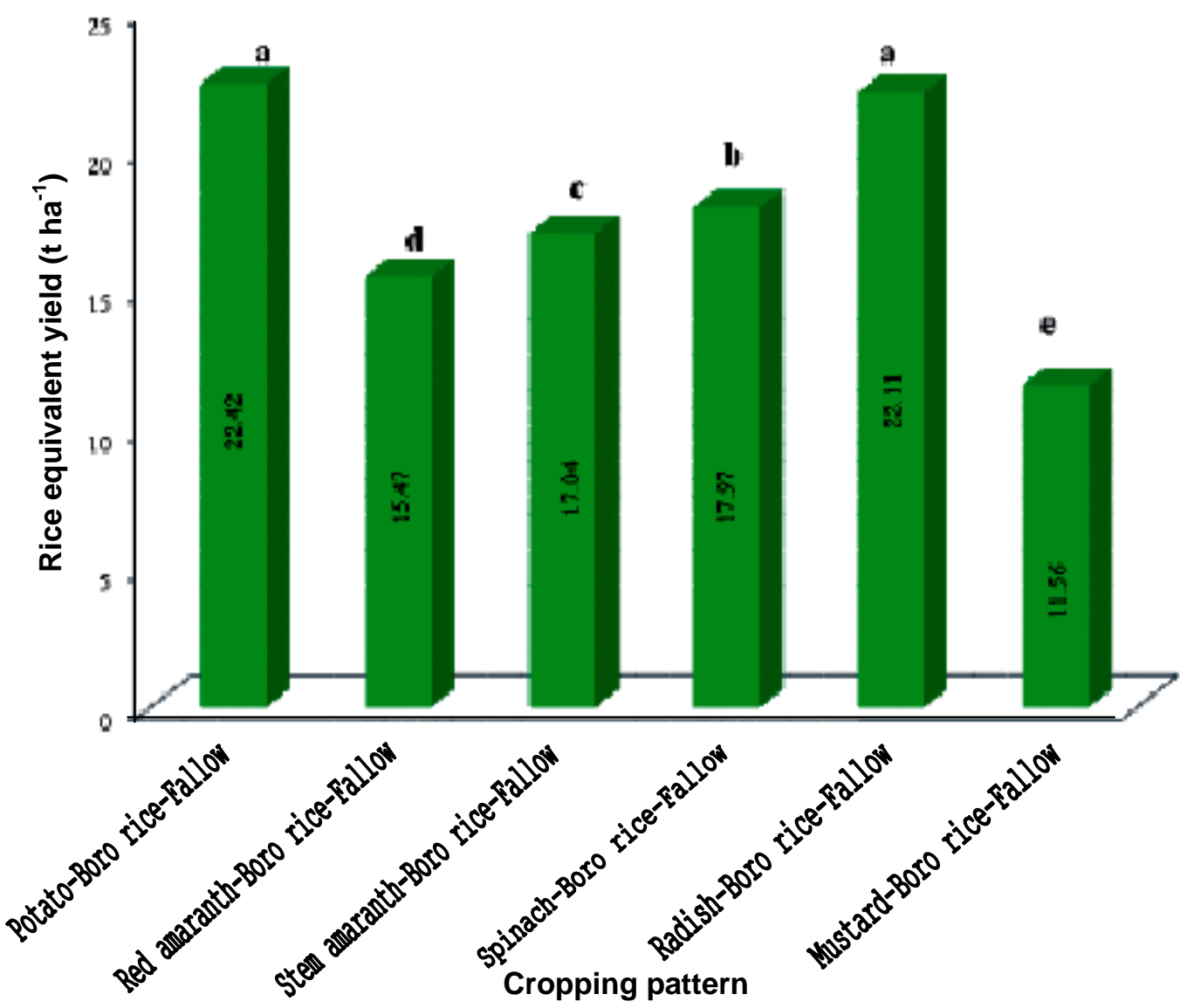

Fig. 3. Rice equivalent grain yield with cropping patterns in Dingaputa haor ecosystem 
The period seems to be sufficient for Boro rice raising one crop in sequence of Fallow- Boro riceSeasonal flood water pattern. But early planting of rice may cause cold injury to rice plant resulting in anther deformation destroying the crop. In order to accommodate another crop in the Fallow-Boro riceSeasonal flood water pattern, short duration vegetable and short duration rice varieties might be possibility for crop diversification in the pattern (Fig. 1, 2 and Table 3).

From the findings of the study it reveals that all the experimental crops were safely harvested due to favourable weather and no occurrence of flash flood indicating that in favourable cropping season, there is an excellent possibility of crop diversification through inclusion of sequential short duration vegetable crops before Boro rice pre-flood and post flood period cropping pattern. The designed cropping patterns tried in the experiments except Mustard-Boro rice- Seasonal flood water the agro-economic productivity was lucrative and farmers' response was very positive to adopt them. The risk of flash flood and cold injury may be avoided by developing appropriate duration of cropping patterns harvestable before the risk period of early flash flood (as occurred on 28 March, 2010) and cold injury for Boro rice during winter.

The designed cropping patterns Potato-Boro rice- Seasonal flood water, Red amaranth-Boro riceSeasonal flood water, Stem amaranth-Boro rice- Seasonal flood water, Spinach-Boro rice- Seasonal flood water, Radish-Boro rice- Seasonal flood water and Mustard-Boro rice- Seasonal flood water in addition to their very high agro-economic productivity may be sustainable one as they can generate more income and employment opportunity for the farming, poor and extreme poor households of the area.

Duration of crops in the main field is the major determinant of number to be accommodated in the sequential cropping pattern. It may be mentioned that this duration does not include the seedling raising period in the nursery. Turn around period, another important determinant when land is prepared in between two crops. The possibility to introduce one crop of vegetable/oil crop in Fallow-Boro riceSeasonal flood water (post flood period) pattern in the context of early flash flood (as on 28 March 2010) has been critically analyzed below.

From Table 2 it is evident that planting/transplanting time followed in the present experiment with sufficient period of turn around period in patterns like Red amaranth-Boro rice- Seasonal flood water and Spinach-Boro rice- Seasonal flood water, there is ample scope of adjustment/manipulation of planting/ transplanting time particularly shifting from 9 November to 20 October and manipulating turn around period from 50 to 25 and 46 to 25 days in the case of Red amaranth-Boro rice- Seasonal flood water and Spinach-Boro rice- Seasonal flood water, respectively which may be considered as risk aversive and the rest four patterns had small turn around period may fall under risk prone period. But except Mustard-Boro rice- Seasonal flood water pattern the performance of all other patterns were excellent in favourable years. In early flash flood affected as on 28 March, 2010. Red amaranth-Boro rice- Seasonal flood water and Spinach-Boro rice- Seasonal flood water however would be aversive of flash flood. Potato- Boro riceSeasonal flood water and Radish- Boro rice- Seasonal flood water would give additional produce of potato and radish, respectively.

\section{Conclusion}

The highest rice equivalent yield (REY) of $22.42 \mathrm{t} \mathrm{ha}^{-1}$ was recorded in the pattern Potato-Boro riceSeasonal flood water and the next highest REY $\left(22.11 \mathrm{t} \mathrm{ha}^{-1}\right)$ was found in pattern Radish-Boro riceSeasonal flood. In rice based vegetable cultivation the highest gross return (Tk.187850.00 ha ${ }^{-1}$ ), gross margin (Tk. $170459.04 \mathrm{ha}^{-1}$ ) and benefit cost ratio (1.88) were obtained from Red amaranth-Boro riceSeasonal flood, and Potato-Boro rice- Seasonal flood, respectively. In all rice based cropping patterns in terms of rice equivalent grain yield, gross return, and gross margin and BCR values. Among the different designed patterns Potato-Boro rice- Seasonal flood gave the performance in terms of rice equivalent grain yield, gross return, gross margin and BCR values.

In early flash flood affected years, the patterns Red amaranth-Boro rice- Seasonal flood and SpinachBoro rice- Seasonal flood would be risk aversive due to their shorter durations for which they may be sustainable ones. Further agronomic trials are needed to refine the proposed shifting of Boro rice to earlier dates along with the use of turn around period to package the generated information into technology. 


\section{References}

Gomez, K.A. and Gomez, A.A. 1984. Statistical Procedure for Agricultural Research. 2nd Ed., A. Willey and Inter-science Publication, John Willey and Sons, New York. pp. 97-111.

Haor Task Force. 1985. Report of the Haor Task Force 1985. Dept. Agril. Exten. Kishorganj.

Hossain, S.M.A and Bhuiya, M.S.U. 2011. Comprehensive Research and Development Approach For Reformation, Reclamation and Renovation of Haor Livelihood Systems in Bangladesh with Special Emphasis on Capacity Building, Infrastructure Development, Productivity Increase, and in situ Job Creation and elimination of Poverty. Dept. Agron., Bangladesh Agril. Uni. University, Mymensingh. Mimeograph. pp. 1-9.

Hossain, S.M.A. and Kashem, A.M. 1995. Performance of different crops after potato. Farming Syst. Res. and Dev. Programme (FSRDP), Research Activities 1990-91. Bangladesh Agric. Univ. Mymensingh.

Hossain, S.M.A., Bhuiya, M.S.U., Islam, M.R., Rabbani, M.G., Islam, S.K. and Ali, A.M. 2010a. Action Research Team. HISAL Project in Kishoregonj site. Action research for vegetable and rice farming as an alternative livelihood option for haor area. Activity Report, Bangladesh Agricultural University, Mymensingh. pp. 1-24.

Hossain, S.M.A., Bhuiya, M.S.U., Islam, M.R., Rabbani, M.G., Islam, S.K. and Ali, A.M. 2010b. Action Research Team. HISAL Project in Kishoregonj site. Agro-Economic performance of selected vegetable/ spices based cropping pattern. pp. 9-10.

Hossain, S.M.A., Bhuiya, M.S.U., Islam, M.R., Rabbani, M.G., Islam, S.K. and Ali, A.M. 2010c. Action Research Team. Action Research Component of HISAL Project in Kishoregonj site. Action Research on Intensification of Field and Homestead Vegetable Production in Haor Area. pp. 11-13.

Hossain, S.M.A., Halim, A., Islam, S.M. and Bhuiya, M.S.U. 1985. Research Activities 1985-86. Farming Syst. Res. and Dev. Programme, Bangladesh Agric. Univ. Mymensingh. pp. 10-15.

LIFCHASA (Livelihood Improvement of Farming Community in Haor Area Through System Approach). 2010. Annual Report. Dept. Agron., Bangladesh Agril. Univ., Mymensingh. 